\title{
Action of 5-Hydroxytryptamine, Substance P, Thyrotropin-Releasing Hormone and Clonidine on Motoneurone Excitability
}

\author{
Paul J. Bédard, L.E. Tremblay, H. Barbeau, M. Filion, R. Maheux, \\ C.L. Richards and T. DiPaolo
}

\begin{abstract}
We have investigated the influence on the excitability of lumbar motoneurons of 5-hydroxytryptamine (5-HT), substance Pand thyrotropin releasing hormone (TRH), three substances which coexist in the same bulbospinal descending pathway and end in large part around motoneurons. We have also studied the effect of clonidine, an alpha 2 noradrenergic agonist. This was done in spinalized rats $\left(T_{5}\right)$ treated three weeks before with 5-7-dihydroxytryptamine. Under those circumstances 5-HTP (I.P.), 5-HT (intrathecally) TRH (I.P. or I.T.) and substance P (I.T.) all elicited a strong excitation of motoneurons as measured by integrated EMG of the hindlimb muscles. Substance $P$ reduced by almost half the subsequent response to 5-HTP, 1 hour and 24 hours later. TRH given acutely did not modify the response to 5-HTP but given chronically for twenty one days by means of Alzet minipump, markedly increased the response to 5-HTP. Clonidine by itself decreased the excitability of motoneurons and antagonized the excitatory effect of 5-HTP and TRH. In a pilot trial, cyproheptadine, a 5-HT antagonist was shown to decrease the manifestations of spasticity in patients with a partial spinal lesion. Clonidine also appears to be of potential use in the treatment of spasticity.
\end{abstract}

RÉSUMÉ: Effet de la 5-hydroxytryptamine, de la substance P, de l'hormone de libération de la thyréostimuline et de la clonidine sur l'excitabilité du motoneurone. Nous avons étudié l'influence de la 5-hydroxytryptamine (5-HT), de la substance P et de l'hormone de libération de la thyréostimuline (TRH), sur l'excitabilité des motoneurones lombaires. Ces trois substances coexistent dans la même voie bulbospinale descendante et se terminent en grande partie autour des motoneurones. Nous avons également étudie l'effet de la clonidine, un agoniste alpha 2 noradrénergique. Ces expériences ont été réalisées chez des rats spinalisés (T5) traités à la 5-7-dihydroxytryptamine, cinq semaines avant leur naissance. Dans ces conditions, la 5-HTP (I.P.), la 5-HT (intrathécal), la TRH (I.P. ou I.T.) et la substance P (I.T.) ont toutes provoqué une forte excitation des motoneurones, telle que mesurée par l'EMG des muscles du train arrière. La substance $\mathrm{P}$ diminuait à peu près de moitié la réponse à la $5-\mathrm{HTP}$, après 1 heure et 24 heures. La TRH administrée sous forme de bolus, ne modifiait pas la réponse à la 5-HTP, mais en administration continue pendant 21 jours au moyen d'une minipompe Alzet, augmentait de façon importante la réponse à la 5-HTP. La clonidine seule diminuait l'excitabilité des motoneurones et contrecarrait l'effet excitateur de la 5-HTP et de la TRH. Dans un essai pilote, nous avons démontré que la cyproheptadine, un antagoniste de la 5-HT, diminuait les manifestations de spasticité chez les patients qui ont une lésion partielle de la moëlle épinière. Il semble possible que la clonidine soit également utile dans le traitement de la spasticité.

Can. J. Neurol. Sci. 1987; 14:506-509

Spasticity can be defined as increased resistance to passive movements which is proportional to velocity and accompanied by hyperreflexia. One of the basic abnormalities in spasticity appears to be hyperexcitability of motoneurons due to loss of supraspinal inhibition. ' Since pharmacological treatment of nervous system disorders generally implies modification of a neurotransmitter system, it becomes important to know what is the role of various neurotransmitter systems on the excitability of motoneurons. There are a great number of amino acids, pep- tides and amines to be found in all regions of the spinal cord and especially in the ventral horn surrounding the motoneurons. We will focus on four substances and their possible role on the excitability of motoneurons. These substances are organized as two separate neuronal systems originating in the brainstem and distributing to all levels of the spinal cord with terminals especially abundant around motoneurons. ${ }^{2,3,4}$

The first system which contains 5-hydroxytryptamine (5-HT) involves cell bodies in the raphe nuclei of the medulla oblongata

From the Laboratoire de Neurobiologie, Faculté de Médicine, Université Laval, Québec, and the Département d'endocrinologie moléculaire, Centre Hospitalier de l'Université Laval, Québec (Dr. DiPaolo)

Reprint requests to: Dr. Paul J. Bédard, Laboratoire de Neurobiologie, Hôpital de l'Enfant-Jésus, 1401, 18e Rue, Québec, Québec, Canada G1J 1Z4 
with axons and terminals distributing in a rich network around motoneurons ${ }^{2,3,4,5}$ It is now clearly established that the cell bodies and axons primarily considered serotonergic also contain at least two peptides: substance P (S.P.) and thyrotropin releasing hormone (TRH) ${ }^{6,7}$ Pelletier et $\mathrm{al}^{8}$ have even shown that substance $\mathrm{P}$ and 5-HT can be identified in the same dense core vesicles of terminals surrounding motoneurons. The coexistence of these three substances in the same terminals so close to motoneurons raises interesting questions. 1) What role do they play individually on the excitability of motoneurons? 2) How do they interact?

The second system whose primary neurotransmitter appears to be noradrenaline originates from the region of the locus coeruleus and projects to the cord in a manner similar to the 5-HT system.

We have studied the role of the above mentioned substances in rats spinalized at the $\mathrm{T} 5$ level and previously treated three weeks before with the neurotoxin 5-7 dihydroxytryptamine (5-7 DHT) administered in the lateral ventricle or intrathecally with or without a concomitant i.p. injection of desipramine to spare the noradrenergic system. The substances to be studied were injected i.p. when possible or administered as in the case of amines or peptides through a long cannula (PE 10) inserted through the cisterna magna and lowered in the subarachnoid space down to the lumbar level.

For testing, the animals were placed on a small padded platform with the hindlimbs hanging freely through holes. Electromyographic signals were recorded from electrodes placed in the flexor and extensor muscles of the thigh. For details see references $9,10,11$. The signals were rectified, integrated and displayed by a pen recorder (Gould 2200). The number of deflections of the pen recording the integrated EMG allowed quantification and comparison of the pre-drug control level of EMG activity with the response to the drug. It should be noted that except in some specific experiments care was taken not to stimulate the hindlimbs in any way so that we recorded "spontaneous" EMG activity as opposed to reflex-evoked activity.

\section{5-Hydroxytryptamine}

5-hydroxytryptamine does not cross the blood brain barrier. When it was given intrathecally via the cannula at doses of 50 to 500 micrograms it elicited a strong increase in EMG activity in both flexor and extensor muscles (Figure 1). The precursor of 5-HT, DL 5-hydroxytryptophan, when given i.p. in doses of 10-100 milligram $/ \mathrm{kg}$ elicited a similar increase in activity lasting more than sixty minutes ${ }^{12,13}$ (Figure 1). The action of 5-HTP was prevented by decarboxylase inhibition ${ }^{12}$ but was mimicked by several agonists including quipazine and 5-methoxy-0dimethyltryptamine. It was blocked by antagonists such as cyproheptadine.

The response to the same dose of 5-HTP increased progressively from day one to day 30 after the spinal transsection. It was however maximal after twenty-four hours if the animals had been previously treated with 5-7 dihydroxytryptamine (5-7DHT) leading us to believe that the progressive increase in the response to 5-HTP was due to denervation supersensitivity of postsynaptic 5-HT receptors. ${ }^{13.14}$ Such a treatment with 5-7 DHT causes at least a $95 \%$ decrease of $5-\mathrm{HT}$ in the spinal cord. ${ }^{10}$ When however a $99 \%$ decrease in 5 -HT was achieved by a chronic three week treatment with parachlorophenylalanine (PCPA), the supersensitivity could not be reproduced, suggesting that in the ventral horn, the trigger for the supersensitivity to 5-HT is not the absence of 5-HT itself but perhaps the absence of the terminals themselves or alternatively of other substances besides 5-HT that are normally contained in those terminals. In this respect it is interesting to remember that substance $\mathrm{P}$ and TRH are colocalized with 5-HT in this pathway.

Our system does not allow us to pinpoint the exact site of action of 5-HT but several arguments are in favor of a direct action on motoneurons. Morphologically there is a dense network of 5-HT fibers surrounding motoneurons. ${ }^{3.4}$ Microiontophoretic application of 5-HT on spinal cord neurons causes depolarization $^{15,16}$ which may however be dependent on the presence of glutamate. Using the sucrose-gap technique, Komissarov and Abramets ${ }^{17}$ have shown that the main action of 5-HT on spinal motoneurons is depolarization and that it is not mediated by interneurons.

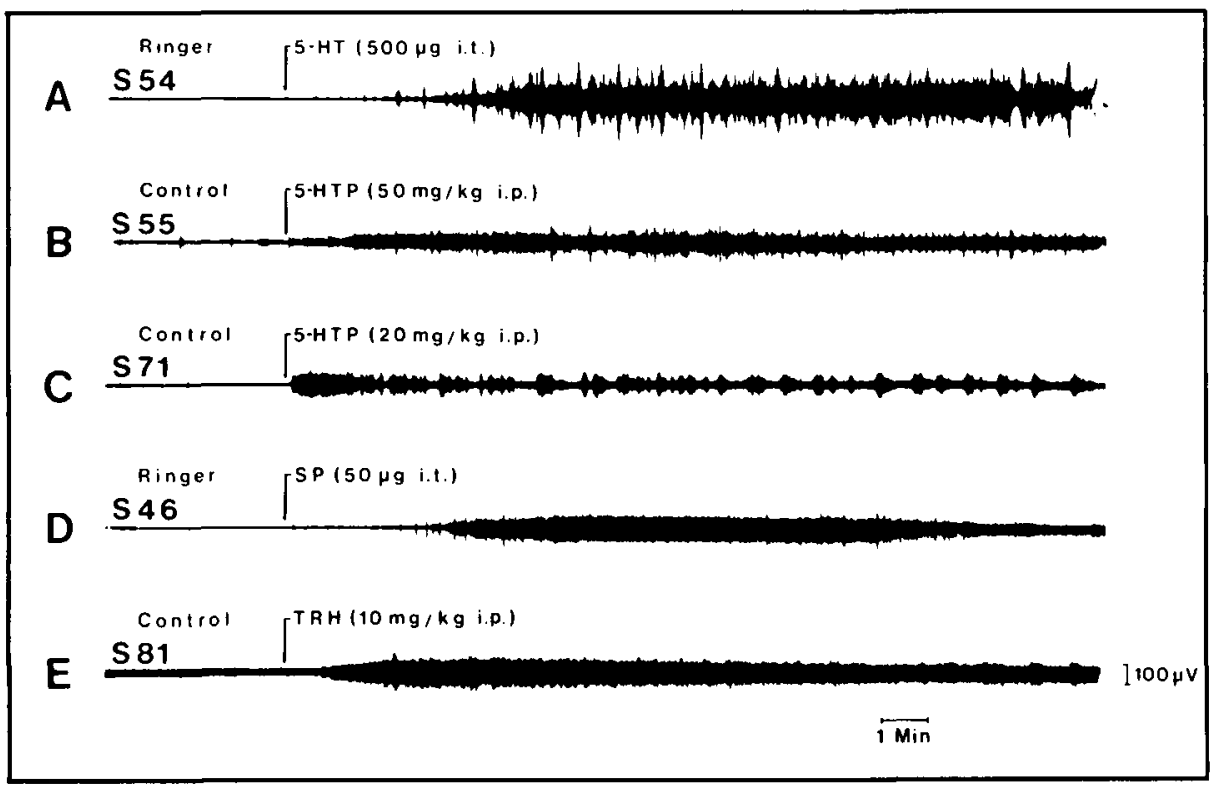

Figure I - Typical electromyographic recording from quadriceps femoris of spinalized rats before and after: A: 5-HT, 500 micrograms administered intrathecally, B:5-HTP. $50 \mathrm{mg} / \mathrm{kg}$ i.p., C: 5-HTP, $20 \mathrm{mg} / \mathrm{kg}$ i.p., D: substance $P, 50$ micrograms intrathecally and $E: T R H$, $10 \mathrm{mg} / \mathrm{kg}$ i.p. Solutions administered intrathecally were preceded by injection of an equal volume of Ringer. 
The precise identity of the 5-HT receptor mediating these excitatory effects is not clear. Sites binding to $\left[{ }^{3} \mathrm{H}\right] 5-\mathrm{HT}$ have been identified in the ventral horn of the rat ${ }^{18.19}$ which suggests that there are a certain number of $5-\mathrm{HT}_{1}$, receptors. However most of the excitatory effects of 5-HT can be abolished by relatively small doses of antagonists which would suggest that $5-\mathrm{HT}_{2}$ receptors are involved.

In summary therefore the predominant effect of $5-\mathrm{HT}$ on spinal motoneurons in vivo is excitation. This excitation appears even increased after spinal transection due to supersensitivity. Thus 5-HT and 5-HT agonists would be expected to increase spasticity and 5-HT antagonists to decrease it. In a pilot study ${ }^{20}$ cyproheptadine was given orally to six patients suffering from spasticity due to spinal cord trauma or multiple sclerosis. All patients were improved. Cyproheptadine proved especially effective against flexor or extensor spasms and against clonus. A slight decrease in maximal muscle contraction was revealed by dynamometry.

More recently Wainberg et $\mathrm{al}^{21}$ have shown in two paraparetic patients that gait can be improved. It should be noted that cyproheptadine was found to be less effective in patients with complete transsection. This may be explained by the fact that under such circumstances, the 5-HT descending pathway is also severed and the excitatory role of $5-\mathrm{HT}$ must be minimal.

\section{Substance P}

As mentioned above, a large proportion of the descending bulbo-spinal 5-HT fibers also contain S.P. and $\mathrm{TRH}^{3}$, two peptides which are presumably synthesized in the cell bodies of the medulla oblongata and transported by axonal flow to their terminal area in the spinal cord.

The dorsal horn receives in addition an important number of SP fibers from the dorsal root ganglion. In the ventral horn, most of the S.P. is located in the terminals of the descending pathway. Substance $P$ and 5-HT have even been observed in the same dense core vesicles in terminals near motoneurons ${ }^{8}$ which suggests that under certain conditions, they might be released together.

Substance $P$, by itself seems to have a strong excitatory effect on motoneurons, as shown in microiontophoresis studies by Konischi and Otsuka ${ }^{22}$ and Henry et al. ${ }^{23}$ In our system, ${ }^{25}$ (Figure 1) when substance $P$ was injected intrathecally in doses ranging from 50 to 500 micrograms, there was a marked increase in EMG activity lasting around forty-five minutes. Three injections of DL5-HTP $20 \mathrm{mg} / \mathrm{kg}$ i.p. given over twenty four hours evoked quantitatively the same EMG response in a group of spinalized rats. If however substance $P$ was administered intrathecally between the first and second injection of 5-HTP, the excitatory response to substance $P$ was seen but the response to 5-HTP was decreased almost by half. The decreased sensitivity was still apparent the next day.

Substance $\mathrm{P}$ has been shown to decrease affinity but to increase density of ${ }^{3} \mathrm{H}-5$ - $\mathrm{HT}$ binding to the spinal cord by Agnati et al ${ }^{18}$ or to decrease the Bmax of $\left[{ }^{3} \mathrm{H}\right] 5$-HT binding to the cord and even more of the $\left[{ }^{3} \mathrm{H}\right]$ Me TRH binding ${ }^{26}$ (see below).

\section{Thyrotropin Releasing Hormone}

TRH, as opposed to substance $P$ is more abundant in the ventral than in the dorsal horn and its role in sensory perception appears minor. When administered i.p. 5-10 mg/kg or i.t. (5-10 micrograms), (Figure 1) TRH has a strong excitatory action ${ }^{9}$ (Tremblay and Bédard, unpublished) which confirms the observation of $\mathrm{Nicoll}^{24}$ in the frog using microiontophoresis. TRH recognition sites have been identified in the ventral horn of mammals. ${ }^{27,28}$

Interestingly, the excitatory effect of TRH is completely blocked by cyproheptadine ${ }^{9}$ which would suggest the TRH recognition site is closely associated to the 5-HT site.

In intact rats, TRH, $10 \mathrm{mg} / \mathrm{kg}$ i.p. increases the level of 5-HIAA in the spinal cord after one hour. This effect which suggests increased turnover is the opposite of that of 5-HT agonists such as quipazine. ${ }^{9}$ It can thus be said that TRH appears to increase the action of 5-HT on motoneurons through both presynaptic and postsynaptic mechanisms.

When tested under the same conditions as substance $P$, TRH, which by itself has an excitatory action does not modify the subsequent response to 5-HTP.

On the other hand, if TRH is administered intrathecally during 21 days with the help of an Alzet minipump connected to the cannula, there is a threefold increase in the EMG response to 5-HTP which would suggest that prolonged exposure to TRH appears necessary to modify the sensitivity of the 5-HT receptors.

The apparent beneficial effect of TRH in amyotrophic lateral sclerosis may be linked in part to these excitatory actions of TRH on remaining motoneurons either by itself or through the 5-HT system. ${ }^{29}$ Other trophic actions may also hopefully contribute. The sense of well being reported by several patients could be explained by a similar cooperation between TRH and 5-HT at the level of the limbic system (Tremblay and Bédard unpublished).

\section{Noradrenaline}

The action of noradrenaline on motoneurons appears more complex than that of 5-HT. Depending on concentration or dose, noradrenaline can either depolarize or hyperpolarize motoneurons. ${ }^{17}$ In our system, systemic administration of L-DOPA although it is reported to increase flexor reflexes in the rat did not affect spontaneous EMG activity in spinalized animals. ${ }^{12}$ No apparent effect was seen either after intrathecal injection of noradrenaline. When the alpha $a_{2}$ agonist clonidine was given $(0.1 \mathrm{mg} / \mathrm{kg}$ i.p.), a clear depression of spontaneous EMG activity was seen in both flexor and extensor muscles. " Clonidine also antagonized the excitatory effect of 5-HTP and this action was antagonized by Yohimbine, an alpha ${ }_{2}$ antagonist. Maximum inhibition was seen with a dose of clonidine of 0.1 $\mathrm{mg} / \mathrm{kg}$ i.p. Beyond that the efficacy seemed to decrease. Clonidine would thus appear at certain doses a useful agent in decreasing motoneuronal excitability and hence spasticity. Interestingly clonidine has other useful actions such as stimulating in certain mammals the spinal generator of locomotion. ${ }^{30.31}$ Antispastic activity of clonidine in humans has been reported by Naftchi, ${ }^{32}$ Nance et al ${ }^{33}$ Galiano et al ${ }^{36}$ as well as Barbeau (1986, personal communication).

\section{ACKNOWLEDGEMENTS}

Supported by MRC grant MT-5750 to P.B.

\section{REFERENCES}

1. Davidoff RA. Antipasticity drugs: Mechanisms of action. Ann Neurol 1985; 17: 107-116. 
2. Dahlström A, Fuxe K. Evidence for the existence of monoamine neurons in the central nervous system. II. Experimentally induced changes in the intraneuronal amine levels of bulbospinal neuron systems. Acta Physiol Scand 1965; Suppl. 247, 64: 1-36.

3. Johansson $\mathrm{O}$, Hökfelt T, Pernow B, et al. Immunohistochemical support for three putative transmitters in a neuron: coexistence of 5-HT, substance P and TRH-like immunoreactivity in medullary neurons projecting to the spinal cord. Neurosci 1981;6: 1857-1881.

4. Steinbusch HWM. Distribution of serotonin-immunoreactivity in the central nervous system of the rat. Cell Bodies and Terminals. Neuroscience 1981; 6: 557-618.

5. Björklund A, Wiklund L, Descarries L. Regeneration and plasticity of central serotoninergic neurons: a review. J Physiol Paris 77: $247-255$

6. Hökfelt $\mathrm{T}$, Ljungdahl $\mathrm{S}$, Steinbusch $\mathrm{H}$, et al. Immunohistochemical evidence of substance P-like immunoreactivity in some 5 -hydroxytryptamine containing neurons in the rat central nervous system. Neuroscience 1978; 3: 517-538.

7. Hökfelt T, Lundberg J, Schultzberg M, et al. Co-existence of peptides and putative transmitters in neurons. In neural peptides and neuronal communication. Costa $\mathrm{E}$, Trabucchi $\mathrm{M}$, eds. Raven Press, New York, 1980: 1-23.

8. Pelletier G, Steinbush HWM, Verhofstad AAJ. Immunoreactive substance $P$ and serotonin present in the same dense-core vesicles. Nature (Lond.) 1981; 293: 71-72.

9. Barbeau H, Bédard P. Similar motor effects of 5-HT and TRH in rats following chronic spinal transection and 5-7 Dihydroxytryptamine injection. Neuropharmacol 1981b; 20: 477-481.

10. Tremblay LE, Bédard PJ, Maheux R, et al. Denervation supersensitivity to 5-hydroxytryptamine in the rat spinal cord is not due to absence of 5-hydroxytrypamine. Brain Res 1985;330: 174-177.

11. Tremblay LE, Bédard PJ. Effects of clonidine on motoneuron excitability in spinalized rats. Neuropharmacol 1986; 25: 41-46.

12. Bédard PJ, Barbeau H, Barbeau G, et al. Progressive increase of motor activity induced by 5-HTP in the rat below a complete section of the spinal cord. Brain Res 1979; 169: 393-397.

13. Barbeau H, Filion M, Bédard PJ. Effects of agonists and antagonists of serotonin on spontaneous hindlimb EMG activity in chronic spinal rats. Neuropharmacol 1981; 20: 611-616.

14. Barbeau H, Bédard PJ. Denervation supersensitivity to 5-hydroxytryptophan (5-HTP) in rats following spinal transection and 5-7 Dihydroxytryptamine injection. Neuropharmacol 1981;20:611-616.

15. White SR, Neuman RS. Facilitation of spinal motoneurone excitability by 5 -hydroxyptamine and noradrenaline. Brain Res 1980 ; 188: 119-127.

16. White SR, Neuman RS. Pharmacological antagonism of facilitatory but not inhibitory effect of serotonin and norepinephrine on excitability of spinal motoneurons. Neuropharmacol 1983; 22: 489-494.

17. Komissarov IV, Abramets II. Effect of monoamines on motoneurons of the isolated rat spinal cord translate VDC 612: 83:612.822 1981 from Neirofiziologiya $1981 ; 12$ : 391-396.
18. Agnati LF, Fuxe K, Benfenati F, et al. On the functional role of coexistence of 5-HT and substance $P$ in bulbospinal 5-HT. Substance $P$ reduces affinity and increases density of ${ }^{3} \mathrm{H}-5 \mathrm{HT}$ binding sites. Acta Physiol Scand 1983; 117: 299-301.

19. Sharif NA, Burt DR, Towle AC, et al. Codepletion of serotonin and TRH induces apparent supersensitivity of spinal TRH receptors. Europ J Pharmacol 1983; 95: 301-304.

20. Barbeau H, Richards CL, Bédard PJ. Action of cyproheptadine in spastic paraplegic patients. J Neurol Neurosurg Psychiat 1982; 45: 923-926.

21. Wainberg M, Barbeau H, Gauther S. Quantitative assessment of the effect of cyproheptadine on spastic paretic gait: a preliminary study. J Neurol 1986; 233: 311-314.

22. Konischi S, Otsuka M. Excitatory action of hypothalamic substance $P$ on spinal motoneurons of newborn rats. Nature 1974; 252: 734-735

23. Henry JL, Krnjevic K, Morris ME. Substance P and spinal neurones. Can J Physiol Pharmacol 1975; 53: 423-432.

24. Nicoll RA. The action of thyrotropin releasing hormone, substance $P$, and related peptides on frog spinal motoneurons. J Pharmacol Exp Ther 1978; 207; 817-824.

25. Tremblay LE, Maheux R, Bédard PJ. Substance $P$ in the lumbar spinal cord of the rat affects the motor response to 5-HTP and TRH. Neuropharmacol 1986; 25: 419-424.

26. Sharif NA, Burt DR. Micromolar substance $P$ reduces spinal receptor binding for thyrotropin-releasing hormone. Possible relevance to neuropeptide coexistence? Neuroscience letters 1983; 43: 245-251.

27. Prasad C, Edwards RM. Thyrotropin-releasing hormone (TRH): apparent receptor binding in rat spinal cord. Brain Res 1984;311: 1.

28. Sharif NA, Burt DR. Limbic, hypothalamic, cortical and spinal regions are enriched in receptors for thyrotropin-releasing hormone: evidence from $\left[{ }^{3} \mathrm{H}\right]$ ultrafilm auto-radiography and correlation with central effects of the tripeptides in rat brain. Neurosc Lett 1985; 60: 337-342.

29. Engel WK, Siddique T, Nicoloff JT. Effect on weakness and spasticity in amyotrophic lateral sclerosis of thyrotropin-releasing hormone. The Lancet 1983; 8341: 73-75.

30. Forssberg H, Grillner S. The locomotion of the acute spinal cat injected with clonidine i.v. Brain Res 1973; 50: 184-186.

31. Barbeau H, Rossignol S. Modulation of the locomotor pattern by noradrenergic, serotonergic and dopaminergic agonists in the adult chronic spinal cat. Abstracts \#47.3 Society for Neuroscience Minneapolis, 1982, p. 163.

32. Naftchi NE. Functional restoration of the traumatically injured spinal cord in cats by clonidine. Science 1982: 217: 1042-1044.

33. Nance $P W$, Shears $A H$, Nance DM. Clonidine in spinal cord injury. Can Med Assoc J 1985; 133: 41-42.

34. Galeano C, Jubelin B, Carmel M, et al. Urodynamic action of clonidine in the chronic spinal cat. Neurol Urodynam 1986; 5: 475-492. 